\title{
Ernst Baasland
}

\section{Parables and Rhetoric in the Sermon on the Mount}

\author{
New Approaches to a Classical Text
}

[Gleichnisse und Rhetorik in der Bergpredigt. Eine neue Annäherung an einen klassischen Text.]

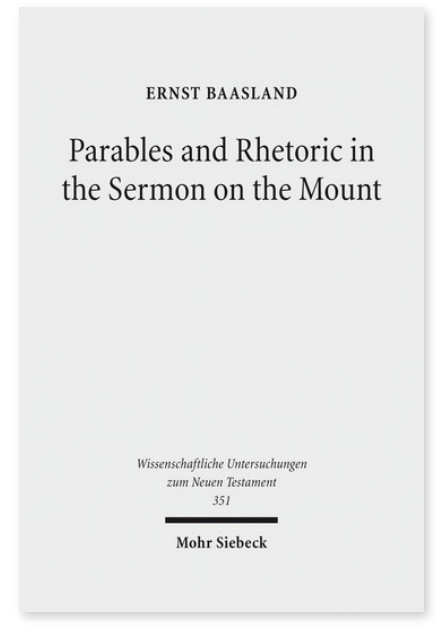

2015. XXXI, 703 Seiten. WUNT I 351

ISBN 978-3-16-154107-0

DOI 10.1628/978-3-16-154107-0

eBook PDF 229,00€

ISBN 978-3-16-154102-5

Leinen $229,00 €$
Veröffentlicht auf Englisch.

Bisher wurden die Gleichnisse in der Bergpredigt (BP) von der Gleichnisforschung zumeist übergangen, umgekehrt wurde die Bedeutung der Gleichnisse in der Forschung zur BP nicht beachtet. Die Tatsache, dass mehr als ein Drittel der Bergpredigt diese Art der Sprache gebraucht, beeinflusst die Deutung des Textes und erlaubt eine neue Annäherung an die Bergpredigt. Ernst Baasland untersucht die Parabeln, die metaphorische Sprache und die Rhetorik der BP. Die rhetorischen Aspekte haben einen großen Einfluss auf die Interpretation des Textes und die rhetorische Gesamtstruktur erklärt den gesamten Aufbau der Predigt. Diese Einblicke in die Rhetorik der Bergpredigt stellen die Quellenfrage daher auf neue Art und Weise.

Die Gleichnisse und die Rhetorik in der Bergpredigt erklären ihren religiösen und philosophischen Standort. Dadurch und durch die Parallelen in jüdischer und griechisch-römischer Literatur erlangen wir ein besseres Verständnis der Lebensphilosophie in der Bergpredigt und neue Einblicke in diesen klassischen Text.

Ernst Baasland Born 1945; since 1971 lecturer, since 1981 professor at MF Norwegian School of Theology in Oslo; 1990-93 dean of the faculty; 1986 guest professor in Tübingen, 1994 in Princeton and 1997-98 in Hong Kong; 1998-2009 bishop in Stavanger; since retirement 2009 guest lecturer in Stellenbosch, SA and 2010 in Berlin; since 2011 affiliated to MF Norwegian School of Theology and School of Mission and Theology, Stavanger.

\section{Jetzt bestellen:}

https://mohrsiebeck.com/buch/parables-and-rhetoric-in-the-sermon-on-the-mount-9783161541070?no_cache=1 order@mohrsiebeck.com

Telefon: +49 (0)7071-923-17

Telefax: +49 (0)7071-51104 